
www.globaljournalseries.com, Email: info@globaljournalseries.com

\title{
SURVEYING THE ASSESSMENT COMPONENTS SUITABILITY FOR ENGINEERING LEARNING IN A CHALLENGING EDUCATIONAL ENVIRONMENT
}

SAMUEL ENEJE AND SCHOLAR

(Received 14 August 2019; Revision Accepted 11 March 2020)

\begin{abstract}
This study used a mixed methodology to investigates the possibility of using blended assessment for engineering education in a challenging learning environment. It discussed the outcome of the evaluation, which is problematized by the influences of an encumbered learning environment. It used the blended engineering models to investigate the circumstances of assessments and its outcomes in a university situated in the sub-Sahara African region. It revealed the experiences of post-internship engineering students using a single blended course. The survey showed that students' knowledge of factors impeding thorough assessment for productivity in the region and advocated ways of improvement. It disclosed past and present assessment percentage shares in addition to suggesting a preferred assessment percentage share required for graduating skilled engineers. The result uncovered where assessment might be situated so that there is a satisfactory learning outcome for engineering programs.
\end{abstract}

KEYWORDS: Blended engineering learning, Challenged educational environments, Assessment outcomes.

\section{INTRODUCTION}

Blended learning is the combination of online and traditional classroom methods. Engineering education in an environment lacking adequate learning and assessment facilities has been described as challenged educational settings and blended activities in such context is under jeopardy (Kehinde, Chen, Ayodele, and Akinwale, 2011). Engineering education started locally in the sub-Saharan Africa around 1960 (NAE, 2015). According to an engineering professional body in Nigeria, literacy escalated from 15,000 to 75,000 graduates from 1990 to 2017 but evidence of credible activities in engineering learning has been low (WES, 2017). In 2018, during the $27^{\text {th }}$ Engineering Assembly, the reports from Nigerian government disclosed that the global competitiveness of local engineers has drastically reduced due to the absence of an updated engineering curriculum and critical engineering training infrastructure in institutions of learning. Nowadays, foreign-trained engineers are highly preferred to locally trained engineers for employment in the local industry because some sub-Saharan African graduates lack adequate skills(The Royal Academy of Engineers, 2011).
In a survey conducted in five sub-Saharan African countries, $40 \%$ of professional engineers stated that engineering learning in their country did not provide graduates with the required skills (Royal Academy of Engineering, 2012).Students usually spend some years at university before they go for an internship programme in the industry. There may be indication that engineering students who are enlisted into the internship and industrial workforce are not equipped with adequate skills required for them to fit into their respective industrial training as they lack responsibility and confidence (Baytiyeh and Naja, 2012). The belief that incompetency in engineering learning and practice locally is prevailing calls for a question on how the students are assessed. Many scholars have studied how skillful an engineer become better after passing through a blended learning system satisfied with an adequate facility such as the works of Onime and Uhomoibhi (2013), Jones and Chew (2015), and Corter, Nickerson, Esche, Chassapis, I m, and Ma, (2007).Kehinde et al. (2011) identified some challenges interfering the blended form of teaching and learning of engineering in institutions situated in most sub-Saharan Africa but

Samuel Eneje, Department of E-research and Technology Enhanced Learning, Lancaster University, Bailrigg, Lancashire, LA1 4YW, United Kingdom,

Scholar, Department of E-research and Technology Enhanced Learning, Lancaster University, Bailrigg, Lancashire, LA1 4YW, United Kingdom, 
could not show the way by which the learners can be assessed. However, literature is yet to tell the proper assessment method of their abilities in engineering education in Sub-Saharan Africa so that students have the required industry's fundamental skills (Matthews, Ryan-Collins, Wells, Sillem, and Wright, 2012). This study focused in offering suitable assessment method for engineering learning.

\section{IMPORTANCE OF THE STUDY}

Without assessment, it will be difficult to ascertain how viable is the learning of engineering in universities has been. Olds, Moskal, and Miller (2013) highlighted the importance of a review of engineering education for answerability. As an instructor in engineering, reviewing the assessment options with respect to sound skill acquisition will enable me to discover lapses that need improvement. From the result of this study, instructors can be able to understand where to prioritize their course's assessment, so that they can graduate students with creditable skills.

\section{RESEARCH QUESTIONS}

This study uses the following to investigate the case; Has the assessment in blended learning in engineering helpful in sound skill acquisition? And which assessment components are likely suitable for engineering learning in a challenging educational environment?

\section{LITERATURE REVIEW}

The literature focuses on blended assessment in a challenging engineering learning environment. For this study, assessment implies the product of evaluation and not the assessment process, the validity of assessment product suggests the relevance of training (skills) to the environment where the student lives and learn (Hassan, 2011). And learning environment refers to the infrastructures (e.g., internet, electricity, equipment, etc.) and workforce abilities (e.g., technical-know-how, managerial capacity, funding, etc.) Kehinde et al. (2011). The blended assessment has been regarded as the best option for building skills in engineering students. In a research conducted in a similar environment, Corter, Nickerson, Esche, and Chassapis (2005) discussed versions of online labs versus hands-on labs in an engineering programme of whose results enabled students learned practical content information adequately from both. Furthermore, the work of Ivanova, Rozeva, and Durcheva,(2016)discovered that a blended model of assessment is the best fit for engineering education. Its outcome is quality learning of skills and knowledge. Kehinde et al. (2011) joined Corter et al. (2005) to underpin the implications of using the blended method in engineering learning. However, the former failed to explain how assessment can achieved in that weakened learning environment it examined. Matthews et al. (2012) observed that literature is yet to tell the proper evaluation method for engineering education in debilitated learning environment. This study will examine blended assessment in engineering programs of the weak technology-mediated learning and suggest the way by which mixed assessment could be achieved.

\section{THEORETICAL FRAMEWORK}

In engineering education measurement, the criterionrelated validity theory is that which supports the extent to which the results of an evaluation correlate with the current happening, and this is the basis for which it is employed in this study (Moskal, Leydens, \& Pavelich,2002). Several theory-tested studies have gone ahead before now that assessed the rationality, scope, and conditions of blended assessment in learning (Thomas, 2011). Kyoung, Merson, Lattuca, and Terenzini,(2015)applied this theory in the study of competence scale for engineering students. This theory was used to explore how assessment outcomes paralleled surrounding influences that are either external or internal, as figure 1 depicts. The subject is engineering students, and the object is the assessments used in their blended courses and contemporary influences.

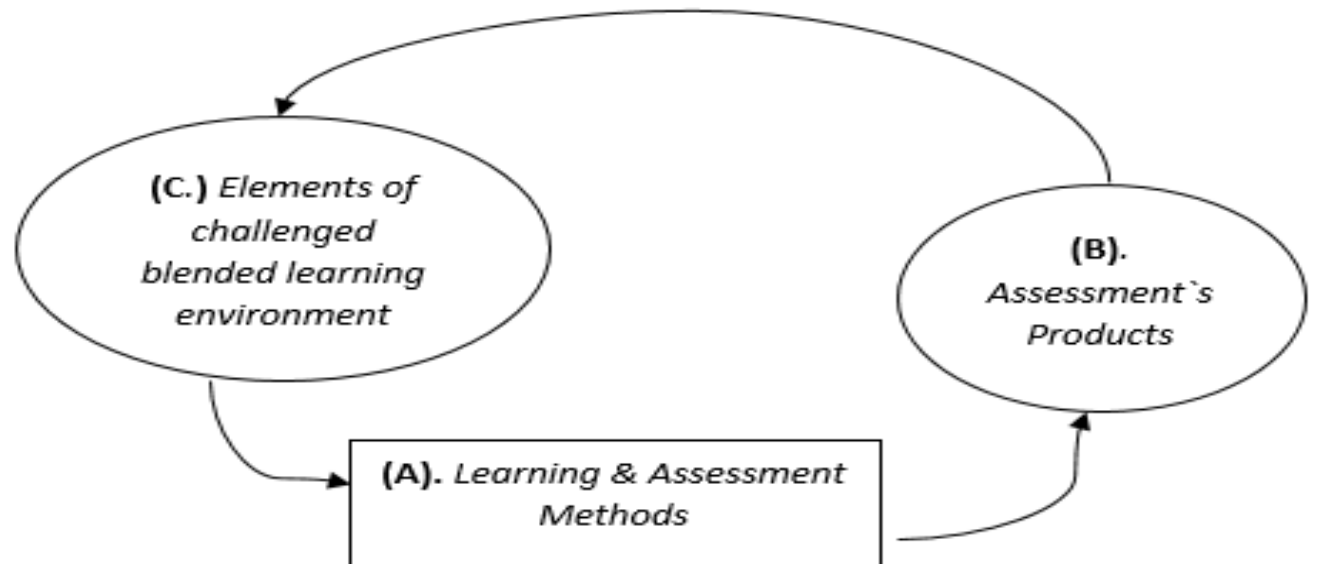

Fig.1:View of the study: Criterion-related validation of assessment product ( adapted from Hassan, (2011) 
DEVELOPING A FRAMEWORK FOR ASSESSING THE ASSESSMENT PRODUCTS IN LEARNING OF ENGINEERING IN A CHALLENGED EDUCATIONAL ENVIRONMENT

Blended, Online, and Offline are the forms where engineering courses may build their assessments. Three studies featured blended learning as the best option for engineering education. However, this study uses them to investigate activities in a challenging educational setting. These studies Nickerson, et al. (2007), Mora, et al. (2012), and Ivanova, et al. (2016) propounded models for learning engineering in the blended form. Figure 2 shows those indicate the three necessary forms of assessments, blended which lies beneath the online and above offline margins.

\begin{tabular}{l|ccc} 
& Continuous & Formative & Summative \\
\hline $\begin{array}{l}\text { Online } \\
\text { Blended } \\
\text { Offline }\end{array}$ & {$\left[\begin{array}{ll} \\
\text { Engineering course }\end{array}\right]$}
\end{tabular}

Figure 2: Representative model of the Nickerson et al., 2007, Mora et al., 2012 and Ivanova et al., 2016 for engineering subject.

In a model for evaluating the effectiveness of online laboratories and simulations in engineering education, Figure 3 outlined the Nickerson et al. (2007) specific Lab aspects that subvert the assessment outcomes in learning laboratories session.

Nickerson et al., 2007's Blended Continuous
Lab aspects used to
measure student's
satisfaction
Overall satisfaction
Feeling of immersion
Ease of use
Obviousness of use
Total time required
Convenience of scheduling
Convenience in access
Clearness of instructions
Reliability of setups

Figure 3: Nickerson et al., 2007's Lab aspects used to measure student's satisfaction correlated with assessment forms

\section{METHODOLOGY AND METHODS}

The initial quantitative step-Priority chart (Slack, 2002) was to thoroughly examine and filter out the threatening and most influencing event in the learning environment, which goes to the next stage of the qualitative process. Full transcripts were prepared and analysed qualitatively. Among students who took the course, 82 students identified and 80 participated. These were those who passed the course and have had their internship training in the industry. The class used for the study is "Computer-Aided Design in Engineering." The survey location is a Federal University in Nigeria. The following factors were listed, and to be put to priority chart as shown on Table 1, of selection by the students: Lack of equipment (denoted with LE), Weak administration and human-related errors (denoted with WA), Insufficient technical-know-how and knowledgeable instructors (denoted with TK), and Operational policies (denoted with OP) (Anekwe, \& Izuchi, 2012).

Tables 1: Chart showing various influential factors and number of selections.

\begin{tabular}{|l|l|l|l|l||l|l|l|l|}
\hline \multicolumn{2}{|l|}{ Selections: } & \multicolumn{7}{|c|}{ After } \\
\hline & LE & WA & TK & OP & LE & WA & TK & OP \\
\hline LE & LE & $\mathrm{x}_{12}$ & $\mathrm{x}_{13}$ & $\mathrm{x}_{14}$ & $\mathbf{0}$ & LE=60 & LE=TK=40 & LE=75 \\
\hline WA & $\mathrm{x}_{21}$ & WA & $\mathrm{x}_{23}$ & $\mathrm{x}_{24}$ & LE=60 & $\mathbf{0}$ & TK=65 & OP=50 \\
\hline TK & $\mathrm{x}_{31}$ & $\mathrm{x}_{32}$ & TK & $\mathrm{x}_{34}$ & LE=TK=40 & TK=65 & $\mathbf{0}$ & TK=50 \\
\hline OP & $\mathrm{x}_{41}$ & $\mathrm{x}_{42}$ & $\mathrm{x}_{43}$ & OP & LE=75 & OP=50 & TK=50 & $\mathbf{0}$ \\
\hline
\end{tabular}




\section{ETHICAL CONSIDERATIONS}

This study has ethical approval, from the participants and institution. Participants were informed that rules of privacy and confidentiality protection have strictly adhered as they remain anonymous throughout the project and after.

\section{DATA ANALYSIS AND FINDINGS}

Based on the current situation, the study rated these lab aspects; overall satisfaction, feeling of immersion, ease of use, the obviousness of use, and total time required, concerning the assessment they had, and these are the summaries. Overall satisfaction: For continuous assessment- Study showed that the students are not satisfied because a wide gap existed between industry and academia; summative- Offline summative assessment was adopted in the past and they suggested online assessment; formative- Instructorstudent feedback was interrupted by poor internet. It suggested more offline than online feedback. Feeling of Immersion: For continuous assessment- They believed that more practice-over problems would get them into the programme and opted for a rise in course's credit load; summative- The study expressed little or no impact of summative; formative- The highest level of engagement could rise through feedback with tutors. Tutors shy away from e-Labs probably because of insufficient tools or expertise. Ease of Use: For continuous assessment- Pre-requisite courses could give a forehand exposure to course; summative- They believed that assessment was incomplete without Lab. Examinations should not be only paper-based; formative- formative scores were embedded on continuous assessment and student could not do review. Obviousness of use: For continuous assessment- over-crowded groups during Labs do not enhance skill acquisition; summative- Examinations should follow suit of e-Labs; formative- Many students do not conform as it is immersed into continuous and it is often ignored and there is need to separate them. Total time required: Continuous- In the past less time was allocated. However, result showed that $70 \%$ of overall time be allocated to e-Labs and $30 \%$ to offline tutorials; summative- Least time is expected; formative assessment was given less time and it was found that it is better matched with continuous on a $70 \%$-time scale.

\section{CONCLUSION}

This study has revealed a suitable form and component for assessing students of engineering so that they possess the required industry's fundamental skills. Sequel to finding that Lack of equipment (LE) prevailed overall factors and has subsequently resulted to a deficient percentage share of assessment, a practice of large percentage share in continuous assessment using e-Labs with an embedded formative evaluation is recommended. It expects that has assessment process been thorough, the technical capacity of the assessment product could have been helpful to the society and learning environment. However, the results showed that the assessment products had had little or no impact on the challenges therefore suggest a search for a new technology for blended assessment. The persisted problem is that the outcomes of engineering learning have not been answerable to issues challenging the assessment. The study recommended the use of various blended assessment components at different times for multiple cases in an institution situated in a debilitated facility for engineering learning setting.

\section{REFERENCES}

Anekwe, J., and Izuchi, M.R., 2012. Quality Assurance Using ICT Best Practices in School-Based Assessment of Students' Learning in Nigerian University Education. African Research Review. https://doi.org/10.4314/afrrev.v6i1.28.

Baytiyeh, H., and Naja, M., 2012. Identifying the challenging factors in the transition from colleges of engineering to employment. European Journal of Engineering Education. https://doi.org/10.1080/03043797.2011.644761.

Corter, J. E., Nickerson, J. V., Esche, S. K., and Chassapis, C., 2005. Remote versus hands-on labs: a comparative study. https://doi.org/10.1109/fie.2004.1408586.

Corter, J. E., Nickerson, J. V., Esche, S. K., Chassapis, C., Im, S., and Ma, J., 2007. Constructing reality: A study of remote, hands-on, and simulated laboratories. ACM Transactions on Computer-Human Interaction (TOCHI), 14(2), 7.

Hassan, O. A. B., 2011. Learning theories and assessment methodologies - an engineering educational perspective. European Journal of Engineering Education. https://doi.org/10.1080/03043797.2011.591486.

Ivanova, M., Rozeva, A., and Durcheva, M., 2016. Towards e-assessment models in engineering education: Problems and solutions. In Lecture Notes in Computer Science (including subseries Lecture Notes in Artificial Intelligence and Lecture Notes in Bioinformatics). https://doi.org/10.1007/978-3-319-47440-3 20.

Jones, L. J. N., and Chew, E., 2015. Blended Learning in Engineering Education: Curriculum Redesign and Development. In Taylor's 7th Teaching and Learning Conference 2014 Proceedings. https://doi.org/10.1007/978-981-287-399-6 40.

Kehinde, L. O., Chen, X., Ayodele, K. P., and Akinwale, O. B., 2011. Developing Remote Labs for Challenged Educational Environments. In Internet Accessible Remote Laboratories. https://doi.org/10.4018/978-1-61350-1863.ch022.

Kyoung R, H., Merson, D., Lattuca, L. R., and Terenzini, P. T., 2015. Validity of the contextual competence scale for engineering students. Journal of Engineering Education. https://doi.org/10.1002/jee.20062. 
Matthews, P., Ryan-Collins, L., Wells, J., Sillem, H., and Wright, H., 2012. Briefing: Engineers for Africa: identifying engineering capacity needs in subSaharan Africa. Proceedings of the Institution of Civil Engineers - Municipal Engineer. https://doi.org/10.1680/muen.12.00052.

Mora, M. C., Sancho-Bru, J. L., Iserte, J. L., and Sánchez, F. T., 2012. An e-assessment approach for evaluation in engineering overcrowded groups. Computers and Education. https://doi.org/10.1016/i.compedu.2012.03.011.

Moskal, B. M., Leydens, J. A., and Pavelich, M. J., 2002. Validity, reliability and the assessment of engineering education. Journal of Engineering Education. $\quad$ https://doi.org/10.1002/j.21689830.2002.tb00714.x

NAE., 2015. Historical Background. Retrieved from Nigerian Academy Of Engineering: http://www.nae.org.ng/aboutus.asp.

Nickerson, J. V., Corter, J. E., Esche, S. K., and Chassapis, C., 2007. A model for evaluating the effectiveness of remote engineering laboratories and simulations in education. Computers \& Education, 49(3), 708725.https://doi.org/10.1016/j.compedu.2005.11. 019.

Olds, B. M., Moskal, B. M., and Miller, R. L., 2013. Assessment in Engineering Education: Evolution, Approaches and Future Collaborations. Journal of Engineering Education. https://doi.org/10.1002/j.2168- 9830.2005.tb00826.x

Onime, C. E., and Uhomoibhi, J. O., 2013. Using interactive video for on-line blended learning in engineering education. In Proceedings - 2013 2nd Experiment@ International Conference, exp.at 2013. https://doi.org/10.1109/ExpAt.2013.6703044.

Royal Academy of Engineering., 2011. Engineering ethics in practice: a guide for engineers. The Royal Academy of Engineers. https://doi.org/https://doi.org/10.1016/j.trd.2017. 12.018 .

Royal Academy of Engineering., 2012, October. Engineers for Africa. Retrieved from Africa-UK Engineering for Development Partnership: https://www.raeng.org.uk/publications/reports/en gineers-corterfor-africa.

Slack, N., 2002. The Importance-Performance Matrix as a Determinant of Improvement Priority. International Journal of Operations \& Production Management. https://doi.org/10.1108/01443579410056803.

Thomas, G., 2011. A typology for the case study in social science following a review of definition, discourse ,andstructure.Qualitative Inquiry: https://doi.org/1077800411409884.

WES., 2017, March. Education in Nigeria. Retrieved from World Education News and Reviews: https://wenr.wes.org/2017/03/education-innigeria. 